\title{
Sustainable land management interventions lead to carbon sequestration in plant biomass and soil in a mixed crop- livestock system: the case of Geda watershed, central highlands of Ethiopia
}

\author{
Hailu Terefe ${ }^{1 *}$ (D) Mekuria Argaw ${ }^{1}$, Lulseged Tamene ${ }^{2}$ and Kindu Mekonnen ${ }^{3}$
}

\begin{abstract}
Background: Sustainable land management interventions were introduced in Geda watershed in 2012 to reduce soil erosion, improve water infiltration, and increase plant-carbon inputs into the soil. This study explored the impact of the interventions on biomass production, carbon stock, and carbon sequestration. Stratified sampling was employed in the main and the dry seasons in the treated and untreated sub-watersheds that are found adjacent to each other. Above- and below-ground plant biomass, soil bulk density and organic carbon in 0-15- and 15-30-cm depths, and soil moisture content in 0-20- and 20-40-cm depths were collected from the crop, grazing, and tree lucerne plots. All analyses were performed based on standard procedures.

Results: Plant biomass production, carbon stock, and carbon sequestration varied highly significantly $(P \leq 0.001)$ among sub-watersheds, landscape positions, and land uses. Higher mean values were observed for treated subwatershed, lower landscape position, and tree lucerne plot. The higher mean values in the lower landscape position of the treated sub-watershed were due to tree lucerne plantation. Similarly, topsoil $(0-15 \mathrm{~cm})$ carbon stock was statistically higher $(P \leq 0.001)$ in the treated sub-watershed and at tree lucerne plot $(P \leq 0.05)$. In addition, carbon stock by sub-surface soil $(15-30 \mathrm{~cm})$ was significantly higher $(P \leq 0.001)$ in the treated sub-watershed under crop and grazing lands but the higher value was in cropland and in the upper position. This could be due to the decomposition of organic materials from biomasses of crops and biological supporting measures (tree lucerne and Phalaris) facilitated by tillage. Six years of sustainable land management interventions led to the sequestration of $12.25,7.77$, and $13.5 \mathrm{Mg} \mathrm{C} \mathrm{ha}^{-1}$ under cropland, tree lucerne, and grazing plots, respectively.

Conclusion: Sustainable land management interventions revealed auspicious ecological impacts in Geda watershed in terms of improving plant biomass production, carbon stock, and correspondingly capturing higher carbon dioxide equivalent taking untreated sub-watershed as a baseline. Prohibition of free grazing was the key element of the intervention to reduce biomass export and increase carbon sequestration in the treated sub-watershed. Thus, sustaining tree lucerne plants as a conservation measure and the prohibition of free grazing practices are principally essential.
\end{abstract}

Keywords: Carbon stock, Landscape position, Land use, Plant biomass, Sub-watershed

\footnotetext{
* Correspondence: terefehailu@gmail.com

${ }^{1}$ Center for Environmental Science, College of Natural Science, Addis Ababa

University, P. O. Box 1176, Addis Ababa, Ethiopia

Full list of author information is available at the end of the article
}

\section{Springer Open}

( ) The Author(s). 2020 Open Access This article is licensed under a Creative Commons Attribution 4.0 International License, which permits use, sharing, adaptation, distribution and reproduction in any medium or format, as long as you give appropriate credit to the original author(s) and the source, provide a link to the Creative Commons licence, and indicate if changes were made. The images or other third party material in this article are included in the article's Creative Commons licence, unless indicated otherwise in a credit line to the material. If material is not included in the article's Creative Commons licence and your intended use is not permitted by statutory regulation or exceeds the permitted use, you will need to obtain permission directly from the copyright holder. To view a copy of this licence, visit http://creativecommons.org/licenses/by/4.0/. 


\section{Background}

Climate change is a threat to the livelihood and overall development of most countries in the world (Akudugu and Alhassan 2012; Asante and Amuakwa-Mensah 2015). It is a major challenge, especially for smallholder farmers in sub-Saharan Africa, where Ethiopia is among the highly affected countries in the region (FAO 2014). Climate change is expected to continue its negative impacts on farm activities in most developing countries (Issahaku and Maharjan 2014). It affects the agricultural sector and more specifically resource-limited poor people because of their weak adaptive capacities to its negative impacts (Keller 2009; Lewis et al. 2011).

Since agriculture, predominantly crop and livestock mixed system, operated by smallholder poor farmers is the backbone of Ethiopia, the impact of climate change is immense in the country. Reports indicated that agriculture is the most vulnerable sector to climate change, especially for the rain-fed conditions (Conway and Schipper 2010; Deressa et al. 2011). In order to reduce the impacts of climate change on the agrarian community, various mitigation and adaptation options have been implemented for decades in Ethiopia (Birhanu 2014; Gashaw 2015). The interventions have started since the mid-1970s with various soil and water conservation practices, and integrated watershed-based interventions were introduced since the late 1980s. Further, sustainable land management (SLM) interventions have been implemented since 2008 (Ademe et al., 2017; Adimassu et al. 2017).

SLM is a systematic approach that combines all possible conservation measures with better synergies and lesser tradeoffs, and it has been implemented on a watershed level at different parts of Ethiopia (Ebabu et al. 2019). SLM practices were designed to increase agricultural productivity, improve ecosystem functions, and enhance resilience to adverse climate impacts (Liniger et al. 2011; Thomas et al. 2018).

Management options that reduce land degradation also reduce $\mathrm{CO}_{2}$ concentration in space by capturing through photosynthesis and storing it in plants and soils in the form of biomass (Tesfay et al. 2019). Thus, SLM interventions such as improved soil and water conservation methods, the introduction of multi-purpose trees, area closure, and grazing managements were introduced in Geda watershed in the central highlands of Ethiopia, since 2012 (Mekonnen 2018; Terefe et al. 2020).

Geda watershed is characterized by a mixed croplivestock farming system where more lands are allocated for crops and grazing with fewer plots for eucalyptus plantation (Terefe et al. 2020). The mixed crop-livestock system is a common practice in the tropics and is a dominant farming typology in Ethiopia (Thornton and Herrero 2015). The system has complex synergies and tradeoffs: improved nutrient cycling due to the direct soil-crop-manure relations and diversified income sources to the household, providing options for investment, security, and a means of saving are among the advantages; however, resource competition, overgrazing, compaction, and soil erosion are among the tradeoffs (Thornton and Herrero, 2015).

In Geda watershed, free grazing on crop and grazing lands is a common practice following the main season crop harvest until the landscape is covered by the next season crops (Terefe et al. 2020). Free grazing practices remove crop residues and all organic resources which need to be decomposed to enrich the soil (Gebremedhin et al. 2001; FAO 2012). Thus, technology introduction to rehabilitate degraded landscape requires careful selection and management options in order to enhance synergies and reduce tradeoffs of the farming system in the face of climate change.

In view of improving ecosystem services and building climate resilience landscape, various SLM interventions were introduced at Geda watershed in 2012 (Terefe et al. 2020). SLM practices include construction of soil and/or stone bunds, terraces, trenches, check dams, percolating pits, planting of tree lucerne at highly degraded plots, combinations of structural and vegetative measures, and most importantly prohibition of free grazing (Ebabu et al. 2019; Terefe et al. 2020). Since the installation of the SLM practices in Geda watershed, evidences were generated on erosion, runoff, and sediment suspension and crop yields (Mekonnen 2018). According to evidences elsewhere (e.g., Nyssen et al. 2008; Hishe et al. 2017), improving the productivity of a degraded landscape through various conservation practices also improves ecosystem services such as soil fertility, water availability, and species richness, which further increased above-ground and below-ground biomasses through sequestering carbon by the vegetation and the soil. Thus, the objective of this study was to explore the effect of SLM interventions on biomass production, carbon sequestration through plant biomass, and the soil as well on the ecosystem carbon stock in Geda watershed by comparing the conserved and non-conserved subwatersheds found adjacent to each other.

\section{Materials and Methods}

\section{Description of the study area}

The study was conducted in Geda watershed, North Shewa Zone of Amhara National, Regional State, Ethiopia, geographically located in Blue Nile basin between $39^{\circ} 40^{\prime} 40^{\prime \prime}$ and $39^{\circ} 41^{\prime} 20^{\prime \prime}$ East longitude and $9^{\circ} 48^{\prime} 40^{\prime \prime}$ and $9^{\circ} 49^{\prime} 20^{\prime \prime}$ ' North latitude (Fig. 1). The watershed has a catchment area of 1056 ha within Gudo Beret and Adisgie villages (Tamene et al. 2015; Terfefe et al. 2020), situated in a highland agro-ecological zone 


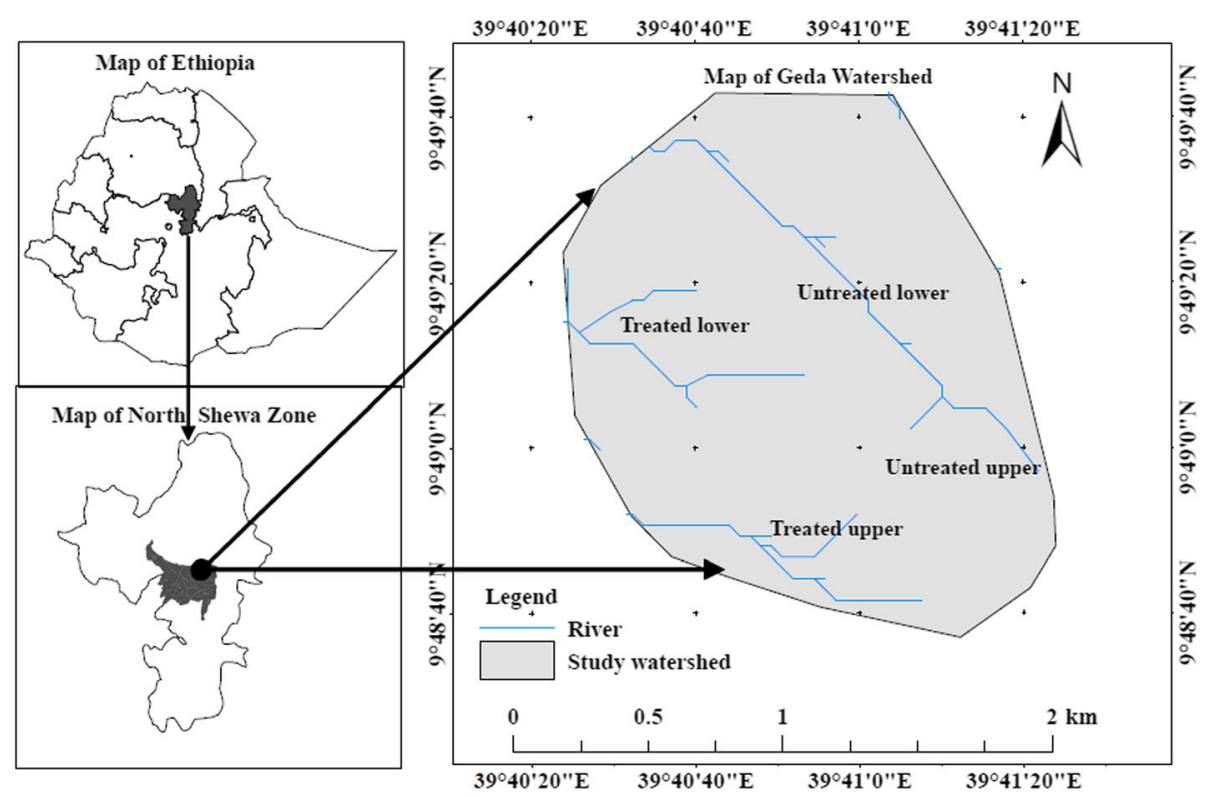

Fig. 1 Map of the study area in Geda watershed

with an elevation of 2865 to 3105 masl. The watershed receives an average annual rainfall of $1277.8-2061.3 \mathrm{~mm}$, and the daily minimum temperature is within the range of 0.5 to $19.5{ }^{\circ} \mathrm{C}$. The maximum daily temperature ranges from 9.5 to $28.5{ }^{\circ} \mathrm{C}$ (Tamene, 2017) (Fig. 2). Rainfall in the study area is bimodal: short rainy season falls between February and April, and the heavy rainy season is between mid-June and mid-September.

Geologically, the site is characterized by volcanic rocks such as rhyolites, trachites, tuffs, and basalts. The major soils are Andosol in the upper parts of the watershed, Fluvisol at the Valley bottoms, Regosol at the eroded parts, and Leptosol on the steep slope areas (Ashagrie 2009; Amare et al. 2013). The watershed is characterized by a mixed crop-livestock farming system with more lands allocated for crop production and grazing, while few plots, especially at the degraded and mountainous areas, are planted with eucalyptus trees. There is severe land degradation mainly in terms of soil erosion on higher slopes of the watershed (Terefe et al. 2020).

In order to rehabilitate the degraded landscape, different conservation measures have been implemented on the one side of Geda watershed since 2012, while the other part was not treated at all. Currently, the untreated sub-watershed is under intensive crop production growing mainly barley, wheat, faba bean, and field pea during the main/wet season (June to September). After the crop is harvested in mid-October, livestock starts grazing on stubbles and plot margins. Thus, following the harvesting time, each farmer transports the produce and hay to homesteads as quickly as possible in order to protect from livestock damage in the field. Then, the area is left for free

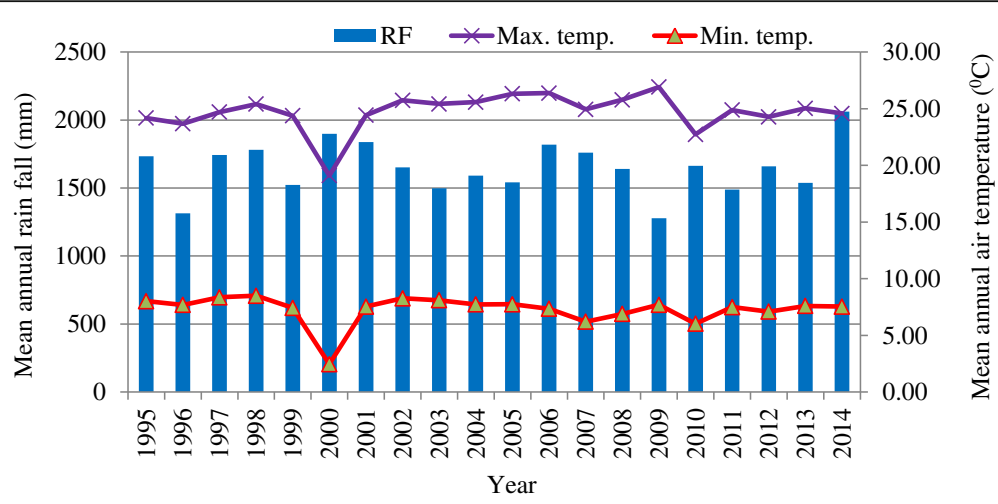

Fig. 2 Mean annual rainfall and air temperature of the study area 
grazing from around November to mid-June until tillage for the next season's crop planting will take place. Cattle, sheep, donkeys, and horses freely graze in the sub-watershed for about 8 months, leaving hardly any soil cover in the landscape, and the cycle continues each year (Terefe et al. 2020).

The other sub-watershed was treated by various SLM intervention options. Major SLM options practiced at the treated sub-watershed include the prohibition of free grazing, soil bunds, and also soil bunds supported by biological interventions mainly with tree lucerne (Chamaecytisus palmensis) and Phalaris (Phalaris acquatica, Phalaris arundinacea), percolation pits, and contour trenches and tree lucerne plantation in the lower landscape position of the treated sub-watershed to rehabilitate highly degraded sections of the landscape. The SLM interventions were more than $80 \mathrm{~km}$ of soil bunds with trenches, $71 \mathrm{~m}^{3}$ of gabion check dams, $730 \mathrm{~m}^{3}$ wooden check dams, 19 percolation pits, and some tree lucerne plantation on highly degraded plots (Tamene 2017; Terefe et al. 2020). Major SLM measures from where data was collected were prohibited grazing, soil bunds, and terraces supported by tree lucerne and Phalaris on croplands; prohibited grazing and contour trenches on grazing lands; and contour trenches and percolation pits on tree lucerne plantation. The size of the treated subwatershed from which data was collected was about 110 ha while the untreated sub-watershed was about 100 ha (Terefe et al. 2020).

\section{Data collection}

Samples on plant biomass were collected in the main biomass production period in 2018 (October for grasses and early maturing crops and November for late-maturing crops) and in the dry season (February 2019), which is the peak nutrient exporting period of the landscape through biomass harvesting and free grazing. These periods were selected to make an adequate comparison of carbon stock and carbon sequestration between the treated and untreated subwatersheds.

In order to increase the accuracy of estimation, the study area was stratified (Pearson et al. 2005) into (1) treated with different SLM interventions and untreated sub-watersheds, (2) upper and lower landscape positions, and (3) land-use systems such as cropland, grazing land, and tree lucerne plot in the lower treated sub-watershed. Then, samples on plant biomass, soil bulk density, soil organic carbon, and soil moisture content were collected from both treated and untreated sub-watersheds in the upper and lower slopes, from croplands, grazing lands, and tree lucerne plantation. We followed the judgment sampling method (EPA 2002) to locate representative sampling sites for both crop and grazing land-use types throughout the sub-watersheds. Accordingly, ten representative plots were identified for each of the two landuse types in each landscape position and each subwatershed. Consequently, samples were collected from a total of 90 plots (two sub-watersheds $\times$ two landscape positions $\times$ two land-use types $\times$ ten replications) including ten plots from tree lucerne plantation at the lower landscape position of the treated sub-watershed.

The main quadrat of $10 \mathrm{~m} \times 10 \mathrm{~m}$ was laid down at each representative plot (Zerihun et al. 2011), and $1 \mathrm{~m} \times$ $1 \mathrm{~m}$ sub-quadrat was used for grasses, herbs, and crops while $2 \mathrm{~m} \times 2 \mathrm{~m}$ sub-quadrat was used for shrubs (mainly tree lucerne) within the $10 \mathrm{~m} \times 10 \mathrm{~m}$ main quadrat (Pearson et al. 2005).

\section{Measuring above-ground biomass for grasses, herbs, and crops}

Above-ground biomass for grasses, herbs, and crops was determined by cutting all the vegetative parts of the plants (grasses, herbs, crops) above the soil surface (Asmare and Gure 2019) in a $1 \mathrm{~m} \times 1 \mathrm{~m}$ quadrat at four corners and at the center of the main quadrat. The total weight of the fresh samples and sub-samples were measured on the spot using spring balance, and the weight of composite fresh sub-samples was also measured, labeled, put in cloth bags, and taken to the laboratory to determine the dry masses (Mekuria et al. 2011; Muluken et al. 2015).

\section{Above-ground and below-ground biomass for tree lucerne}

The dominant shrub at the watershed was tree lucerne which was introduced as part of the sustainable land management element. In order to determine the biomass of the tree lucerne, partial harvest method was used (Mekuria et al. 2011); accordingly, a total of 35 individual tree lucerne plants were harvested; 25 of which from crop and grazing lands where they provide biological support and ten of which from tree lucerne plantation in the lower landscape position of the treated sub-watershed. The reason for applying the partial harvesting technique was that harvesting all the tree lucerne in the sampling plot is a destruction of the conservation measures that could negatively affect the conservation outcomes on the one hand and show the wrong practice to the community on the other hand. Thus, after partial harvesting of the tree lucerne small branches with leaves, big branches and stem were separated and fresh weight of all parts was measured on the spot, and the weight of sub-samples was taken from all parts as per the ratio of the weight of the parts and brought to the laboratory to determine the dry mass. Belowground biomass for tree lucerne was determined by 
multiplying the above-ground biomass (AGB) by 0.27 (Manaye et al. 2019) as recommended by the IPCC (2006) using root to shoot ratio of the tropical mountain system. Below-ground biomass was estimated in tree lucerne but not in other plant species because the roots of herbs and crops are expected to decompose in the given conservation periods and can be thus captured in the soil $\mathrm{C}$ pool which is not true for the main roots of tree lucerne. However, the active roots of some crop/herb/grass in all land uses were not included in $\mathrm{C}$ stock estimation. Thus, the ecosystem $\mathrm{C}$ stock might be underestimated.

\section{Laboratory analysis of the plant biomass}

In the laboratory, all sub-samples were oven-dried at 70 ${ }^{\circ} \mathrm{C}$ for $48 \mathrm{~h}$ (Pearson et al. 2005; Muluken et al. 2015) and weighed using a digital balance. Then, dry mass per plot was calculated as follows:

$$
\begin{aligned}
& \text { Dry mass of the sample per plot } \\
& =(\text { sub-sample dry mass/sub-sample wet mass }) \\
& \quad \times \text { total mass of the plot sample }
\end{aligned}
$$

(Pearson et al. 2005; Muluken et al. 2015).

This was converted into a hectare basis by multiplying the plot dry mass by an expansion factor (Pearson et al. 2005) calculated from the plot size.

$$
\text { Extension factor }=10,000 \mathrm{~m}^{2} / \text { plot area }\left(\mathrm{m}^{2}\right)
$$

Carbon stock for tree lucerne was determined by multiplying the oven-dry mass by the default value of the $\mathrm{C}$ fraction $(0.47)$ as recommended by the IPCC (2006) (Muluken et al. 2015), whereas C stock for grasses, herbs, and crops was determined by multiplying the oven-dry mass by 0.5 (IPCC 2006; Mekuria et al. 2011). In order to understand $\mathrm{CO}_{2}$ mitigation potential of SLM intervention options in the study area, the carbon stock was converted to tons of $\mathrm{CO}_{2}$ equivalent by multiplying the $\mathrm{C}$ stock by

$$
\text { 3.67(molecular weight ratio of } \mathrm{CO}_{2} \text { to } \mathrm{O}_{2} \text { which is } 44 / 12 \text { ) }
$$

\section{(Muluken et al. 2015)}

\section{Soil carbon determination}

In the dry season (Feb. 2019), composite soil samples were collected from the sampling plots in two depths: $0-15 \mathrm{~cm}$ and $15-30 \mathrm{~cm}$. The samples were air-dried in the laboratory, ground, and sieved through a 2-mm sieve for \% OC analysis (Pearson et al. 2005). OC was analyzed using the Walkley-Black method (Walkley and Black 1934). Bulk densities of the soils were determined from the mass of an oven-dried soil at $105{ }^{\circ} \mathrm{C}$ for $48 \mathrm{~h}$ divided by the volume of the core sampler (Wilke 2005). Soil organic carbon (SOC) stock was determined from bulk density $\left(\mathrm{g} \mathrm{cm}^{-3}\right)$, sampling depth $(\mathrm{cm})$, and $\mathrm{OC}$ concentration (\%) obtained from the laboratory analysis (Pearson et al. 2005; Manaye et al. 2019). Thus, soil organic $\mathrm{C}$ stocks $\left(\mathrm{Mg} \mathrm{C} \mathrm{ha}{ }^{-1}\right)$ in the $0-0.15-\mathrm{m}$ and $0.15-0.30-\mathrm{m}$ depths were separately calculated as follows:

$$
\text { SOC }=\text { OC }(\%) \times \text { Bd } \times \text { depth }(\mathrm{m}) \times 10,000 \mathrm{~m}^{2} \mathrm{ha}^{-1}
$$

(Mekuria et al. 2011)

where $\mathrm{SOC}=$ soil organic carbon $\left(\mathrm{Mg} \mathrm{ha}^{-1}\right), \mathrm{OC}=$ the soil $\mathrm{C}$ concentration (\%), $\mathrm{Bd}=$ bulk stock $\left(\mathrm{Mg} \mathrm{m}^{-3}\right)$, depth $=$ soil sampling depth $(\mathrm{m})$, and $10,000 \mathrm{~m}^{2} \mathrm{ha}^{-1}=$ conversion factor to hectare basis.

Finally, the ecosystem carbon stocks were determined by adding all carbon pools from the plant biomass and the soil for both the treated and untreated subwatersheds, and the exported $C$ stock was determined by subtracting the dry season plant biomass from the main season plant biomass. Likewise, $\mathrm{C}$ sequestration of the system was determined by subtracting the exported carbon from $\mathrm{C}$ stock at the peak (main season) landscape production season.

\section{Soil moisture assessment}

Gravimetric soil moisture content was determined at 0 $20-\mathrm{cm}$ and $20-40-\mathrm{cm}$ depths in the main season and at the surface $0-20-\mathrm{cm}$ depth in the dry season.

\section{Statistical analysis}

Analysis of variance (ANOVA) was conducted to evaluate the effects of SLM interventions, landscape position, and land-use types on biomass production, carbon stocks/sequestration by plant biomass and the soil, and ecosystem carbon stock. A three-way ANOVA (SLM practice, landscape position, and landuse types) was performed using the general linear model of SAS version 9.4 statistical software (SAS Institute 2016). Least significant differences and Duncan's mean separation at $P \leq 0.05$ were used to separate treatment means when there was a significant treatment effect using the LSMEANS procedure. Excel was used to make bar graphs.

\section{Results}

Effects of SLM interventions on plant biomass production and retention

ANOVA revealed highly statistical differences $(P \leq$ 0.001 ) for plant biomass production in the main season and retained and exported plant biomass in subwatersheds and land-use types (Table 1). Significantly 
higher plant biomass was observed in the treated subwatershed than in the untreated one, both in the main and dry seasons. In addition, the lower landscape position in the treated sub-watershed revealed statistically higher plant biomass in both seasons which was driven from tree lucerne as evident by the comparison of the land-use types (Table 1).

A total of 10.63 and $7.62 \mathrm{Mgha}^{-1}$ plant biomasses were recorded in the treated sub-watershed in the main cropping season and the dry periods, respectively. In contrast, the total plant biomasses recorded in the untreated sub-watershed were 5.91 and 0.33 $\mathrm{Mg} \mathrm{ha}^{-1}$ in the main and dry periods, respectively. No statistical difference was observed for exported plant biomass in sub-watershed by landscape interactions.

Exported plant biomass was significantly higher $(P \leq$ $0.001)$ in untreated sub-watershed both in the upper and lower landscape positions, compared to the treated subwatershed. About $94.42 \%$ of the biomass was exported from the untreated sub-watershed by harvesting and transporting to homesteads and by free grazing, whereas the amount of plant biomass exported from the treated sub-watershed was much lower (28.32\%) compared to the conventional one; most of which were through crop harvesting and transporting to homesteads. Free grazing

Table 1 Effects of sub-watersheds, landscape positions, and land use on plant biomass production and biomass export

\begin{tabular}{|c|c|c|c|c|}
\hline & \multirow[t]{2}{*}{$N$} & \multicolumn{2}{|c|}{ Plant biomass $\left(\mathrm{Mg} \mathrm{ha}^{-1}\right)$} & \multirow{2}{*}{$\begin{array}{l}\text { Exported } \\
\text { plant } \\
\text { biomass } \\
\left(\mathrm{Mg} \mathrm{ha}^{-1}\right)\end{array}$} \\
\hline & & Main season & Dry season & \\
\hline \multicolumn{5}{|l|}{ Sub-watershed (SW) } \\
\hline Untreated & 40 & $5.91^{\mathrm{b}}$ & $0.33^{b}$ & $5.58^{\mathrm{a}}$ \\
\hline Treated & 50 & $10.63^{\mathrm{a}}$ & $7.62^{\mathrm{a}}$ & $3.01^{\mathrm{b}}$ \\
\hline \multicolumn{5}{|c|}{ Landscape position (LP) } \\
\hline Untreated upper & 20 & $5.38^{b}$ & $0.33^{c}$ & $5.05^{\mathrm{a}}$ \\
\hline Lower & 20 & $6.44^{b}$ & $0.31^{c}$ & $6.12^{\mathrm{a}}$ \\
\hline Treated upper & 20 & $5.77^{\mathrm{b}}$ & $2.21^{\mathrm{b}}$ & $3.56^{\mathrm{b}}$ \\
\hline Lower & 30 & $10.97^{\mathrm{a}}$ & $7.36^{\mathrm{a}}$ & $3.61^{\mathrm{b}}$ \\
\hline \multicolumn{5}{|l|}{ Land-use types (LU) } \\
\hline Untreated crop & 20 & $6.92^{b}$ & $0.41^{c}$ & $6.51^{\mathrm{a}}$ \\
\hline Grazing & 20 & $4.90^{c}$ & $0.24^{c}$ & $4.66^{\mathrm{b}}$ \\
\hline Treated crop & 20 & $8.09^{b}$ & $1.95^{\mathrm{b}}$ & $6.14^{\mathrm{ab}}$ \\
\hline Grazing & 20 & $4.49^{c}$ & $1.69^{\mathrm{b}}$ & $2.80^{c}$ \\
\hline Tree lucerne & 10 & $19.31^{\mathrm{a}}$ & $19.23^{\mathrm{a}}$ & $0.08^{d}$ \\
\hline P-SW & & $* * *$ & $* * *$ & $* * *$ \\
\hline$P-S W * L P$ & & $* * *$ & $* * *$ & ns \\
\hline$P-S W^{*} L U$ & & $* * *$ & $* * *$ & $* * *$ \\
\hline
\end{tabular}

Means within columns under each topic followed by different letters are significantly different from each other at $P \leq 0.05$; ${ }^{* * *}$ significant at $P \leq 0.001$; ns non-significant removed nearly all crop residues and above-ground organic materials left from harvesting and transporting in the untreated sub-watershed (Fig. 3).

SLM interventions did not show a significant effect on croplands in exported plant biomass, but it showed a statistical difference for grazing lands. Among the landuse types, tree lucerne exhibited the higher biomass in both the main and dry seasons (Fig. 4).

There was a strong positive correlation between the main season plant biomass production and the moisture contents of the soils both at the top $0-20-\mathrm{cm}$ and the sub-surface $20-40-\mathrm{cm}$ depths in the treated subwatershed (Table 2) which might enhance the main season plant biomass production in this sub-watershed compared to the conventional one.

\section{Effects of SLM interventions on biomass carbon stocks/ sequestration}

ANOVA exhibited highly significant differences $(P \leq$ 0.001) for biomass carbon stock among sub-watersheds, landscape positions, and land uses. Here, the dry season carbon stock was considered as the sequestered carbon for it was not exported from the system by free grazing or biomass transport. Higher mean values were observed in the treated sub-watershed, in the lower landscape of the treated sub-watershed, and at tree lucerne plots in the lower landscape of the treated sub-watershed. Consequently, there were significantly higher $\mathrm{CO}_{2}$ equivalent of the sequestered carbon by plant biomass $(P \leq 0.001)$ in the treated sub-watershed, lower landscape position of the treated sub-watershed, and tree lucerne plots. Tree lucerne plantation showed the highest mean carbon stock of $9.15 \pm 0.46 \mathrm{Mg} \mathrm{ha}^{-1}$ and carbon sequestration of $9.01 \pm 0.57 \mathrm{Mg} \mathrm{ha}^{-1}$ (33.07 $\mathrm{CO}_{2}$ equivalents). Furthermore, carbon dioxide equivalent was statistically $(P \leq$ 0.001) higher in the treated sub-watershed both in landscape level and land-use types. On the other hand, statistically higher mean values $(P \leq 0.001)$ were observed for exported carbon in the untreated subwatershed at both crop and grazing lands (Table 3). The effect of tree lucerne plantation as SLM intervention option was significant for both the main and dry season carbon stock. However, SLM measures did not statistically affect the main season carbon stocks by crop and grazing lands compared to the untreated sub-watershed, but it had a significant effect on dry season carbon stock of these land uses.

Effects of SLM interventions on soil organic carbon stocks ANOVA revealed significant differences for total soil organic carbon stock among sub-watersheds $(P \leq 0.001)$, landscape positions $(P \leq 0.05)$, and land-use types $(P \leq$ $0.01)$. Higher mean values were observed in the treated sub-watershed, upper landscape position, and cropland 


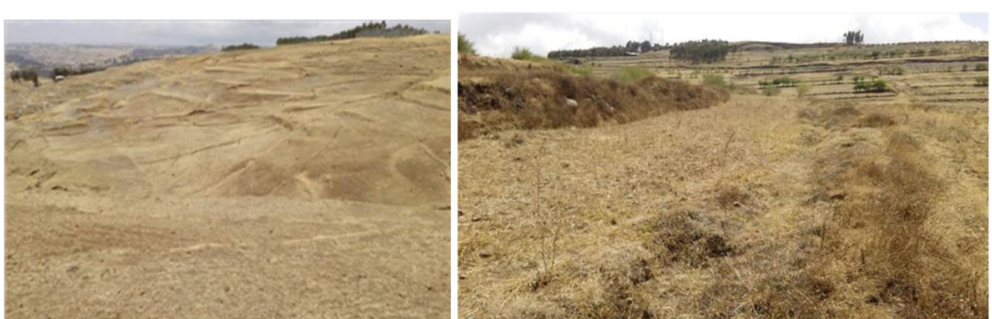

Fig. 3 Plant biomass retention status of sub-watersheds following main season crop harvest: untreated subwatershed (left) showing plant biomass export by free grazing and transporting to homesteads; and treated subwatershed (right) showing the presence of ample crop residues and other organic plant biomass

of the treated sub-watershed. The soils in the treated sub-watershed exhibited significantly higher mean carbon stock of $24.40 \pm 4.77 \mathrm{Mgha}^{-1}$ than the untreated sub-watershed, which revealed a mean value of $16.06 \pm$ $3.59 \mathrm{Mg} \mathrm{ha}^{-1}$. Likewise, $\mathrm{CO}_{2}$ equivalent of the soil organic carbon was statistically higher $(P \leq 0.001)$ in the treated sub-watershed, upper landscape position $(P \leq$ $0.05)$, and cropland $(P \leq 0.01)$ of the treated sub-watershed (Table 4). Furthermore, the soils on the cropland accumulated the highest mean $\mathrm{CO}_{2}$ equivalent of 100.66 $\pm 14.45 \mathrm{Mg} \mathrm{ha}^{-1}$ in the treated sub-watershed.

Landscape position did not show a statistical difference in soil carbon stock except for sub-soil (15-30-cm depth) in the treated sub-watershed, which showed a statistically higher mean value of $12.16 \pm 2.33$. Further, statistically higher soil carbon stock was observed in tree lucerne on the surface $(0-15 \mathrm{~cm})$ and for cropland in the sub-surface $(15-30-\mathrm{cm}$ depths) in the treated subwatershed compared with other land-use types.

\section{Ecosystem carbon stock}

ANOVA displayed highly significant differences $(P \leq$ 0.001) for ecosystem carbon stock between subwatersheds with higher mean value observed in the

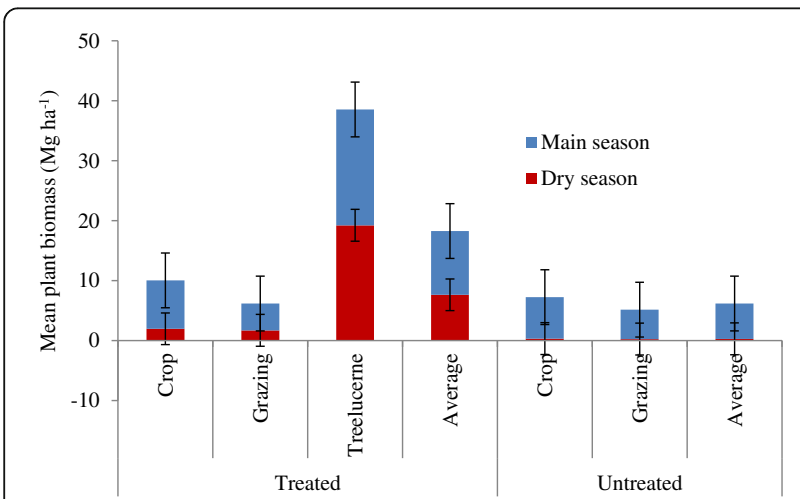

Fig. 4 Mean plant biomass estimation by sub-watersheds \& land-use types, both in the main and dry seasons in Geda watershed. Error bars represent standard errors of the mean treated sub-watershed. Furthermore, land-use types showed statistical $(P \leq 0.01)$ differences in ecosystem carbon stock, with higher mean values in tree lucerne and cropland in the treated sub-watershed. Yet, landscape positions did not show a significant difference within the sub-watersheds (Table 5). Nevertheless, in the treated sub-watershed, the upper landscape position showed a statistically higher mean value for soil carbon stock while the lower landscape showed a significantly higher mean value for plant carbon stock. In the treated sub-watershed, tree lucerne plantation demonstrated the higher ecosystem carbon stock through plant biomass, whereas the cropland showed the higher mean value of soil carbon stock.

Generally, the treated sub-watershed stored significantly higher carbon through the plant biomass and the soil compared to the untreated sub-watershed. In contrast, although a considerable amount of carbon was captured by plant biomass in the main season, extremely lower carbon stock was observed from plant biomass in the untreated sub-watershed (Fig. 5).

The effect of SLM interventions on the ecosystem carbon stock was appreciable. About $10-14 \mathrm{Mg} \mathrm{C} \mathrm{ha}^{-1}$ was stored in the treated sub-watershed due to the introduction of the SLM technologies taking the conventional practice in the untreated sub-watershed as a baseline (Fig. 6).

Table 2 Correlation between plant biomass production and soil moisture conditions

\begin{tabular}{llllll}
\hline & PB & MSCS & CS & SM $(20 \mathrm{~cm})$ & SM $(40 \mathrm{~cm})$ \\
\hline Plant biomass & 1 & & & & \\
Main season C stock & $0.999^{\mathrm{a}}$ & 1 & & & \\
C sequestered & $0.851^{\mathrm{a}}$ & $0.832^{\mathrm{a}}$ & 1 & & \\
Soil moisture (20 cm) & $0.707^{\mathrm{a}}$ & $0.694^{\mathrm{a}}$ & $0.803^{\mathrm{a}}$ & 1 & \\
Soil moisture $(40 \mathrm{~cm})$ & $0.694^{\mathrm{a}}$ & $0.641^{\mathrm{a}}$ & $0.782^{\mathrm{a}}$ & $0.932^{\mathrm{a}}$ & 1 \\
\hline
\end{tabular}

${ }^{a}$ Correlation is significant at the 0.01 level (two-tailed); $P B$ plant biomass, MSCS main season carbon stock, CS carbon sequestered, $S M(20 \mathrm{~cm})$ soil moisture at $20-\mathrm{cm}$ depth, $S M(40 \mathrm{~cm})$ soil moisture at $40-\mathrm{cm}$ depth 
Table 3 Effects of sub-watersheds, landscape positions, and land-use types on biomass carbon stock and exported and sequestered carbon

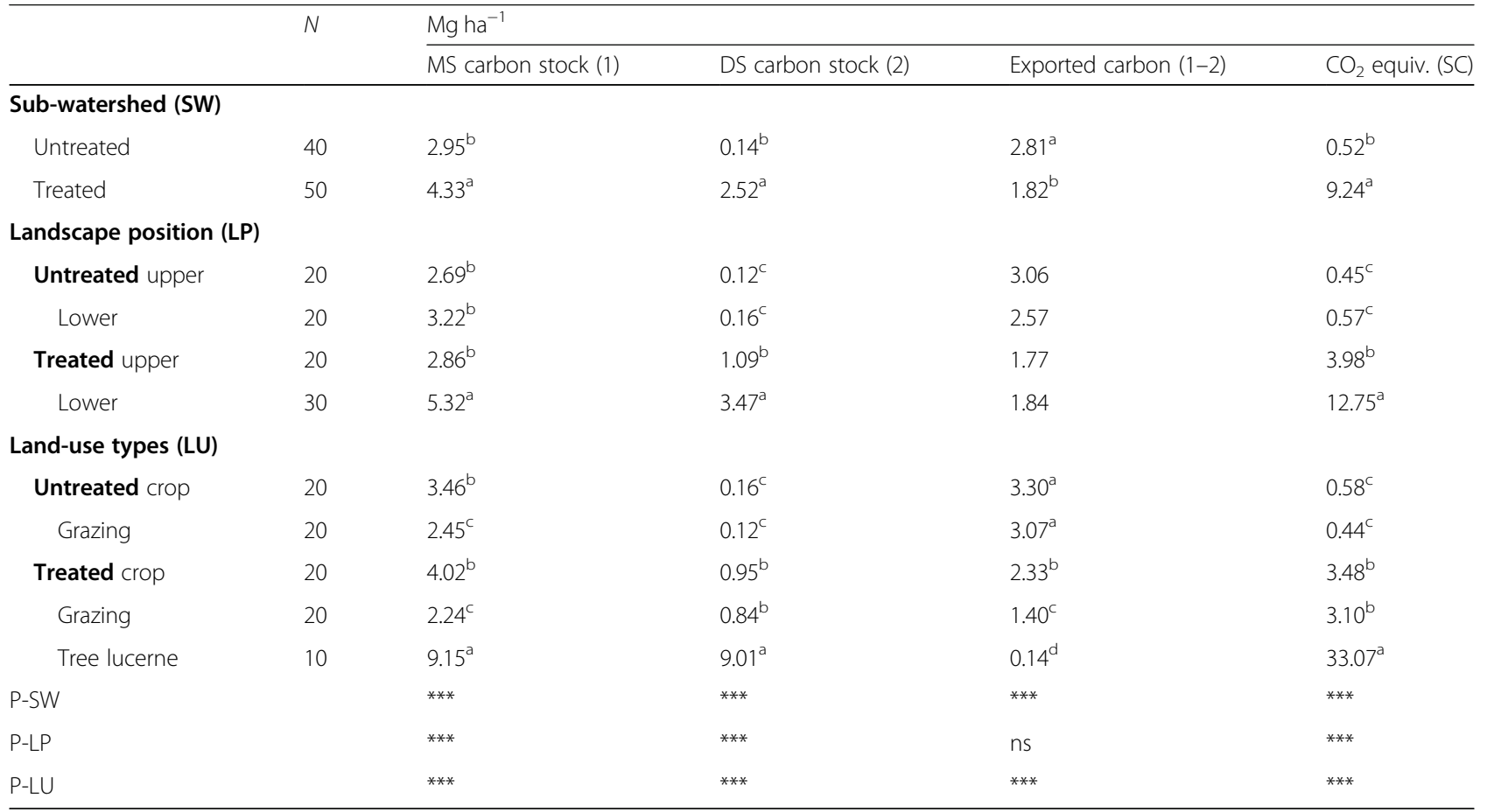

Means within columns under each topic followed by different letter(s) are significantly different from each other at $P \leq 0.05$; ***significant at $P \leq 0.001 ; n s$ nonsignificant, MS main season, DS dry season, equiv. equivalent

Table 4 Effects of sub-watersheds, landscape positions, and land use on the soil carbon stocks

\begin{tabular}{|c|c|c|c|c|c|}
\hline & \multirow[t]{2}{*}{ N } & \multicolumn{4}{|c|}{ Surface and sub-surface soil carbon stocks ( $\mathrm{Mg} \mathrm{ha}^{-1}$ ) } \\
\hline & & $0-15 \mathrm{~cm}$ & $15-30 \mathrm{~cm}$ & Total $(0-30 \mathrm{~cm})$ & $\mathrm{CO}_{2}$ equiv. \\
\hline \multicolumn{6}{|l|}{ Sub-watershed (SW) } \\
\hline Untreated & 40 & $8.70^{\mathrm{b}}$ & $7.36^{\mathrm{b}}$ & $16.06^{\mathrm{b}}$ & $58.92^{\mathrm{b}}$ \\
\hline Treated & 50 & $14.45^{\mathrm{a}}$ & $9.95^{\mathrm{a}}$ & $24.40^{\mathrm{a}}$ & $89.55^{\mathrm{a}}$ \\
\hline \multicolumn{6}{|c|}{ Landscape position (LP) } \\
\hline Untreated upper & 20 & $8.66^{b}$ & $7.63^{\mathrm{b}}$ & $16.29^{c}$ & $59.80^{c}$ \\
\hline Lower & 20 & $8.73^{b}$ & $7.09^{\mathrm{b}}$ & $15.82^{c}$ & $58.05^{c}$ \\
\hline Treated upper & 20 & $13.79^{\mathrm{a}}$ & $12.16^{\mathrm{a}}$ & $25.95^{\mathrm{a}}$ & $95.21^{\mathrm{a}}$ \\
\hline Lower & 30 & $14.90^{\mathrm{a}}$ & $8.48^{\mathrm{b}}$ & $23.38^{b}$ & $85.77^{\mathrm{b}}$ \\
\hline \multicolumn{6}{|l|}{ Land-use types (LU) } \\
\hline Untreated $c r o p$ & 20 & $8.34^{c}$ & $7.62^{c}$ & $15.97^{c}$ & $58.59^{c}$ \\
\hline Grazing & 20 & $9.05^{\mathrm{C}}$ & $7.10^{c}$ & $16.15^{c}$ & $59.26^{c}$ \\
\hline Treated crop & 20 & $14.65^{b}$ & $12.98^{\mathrm{a}}$ & $27.43^{\mathrm{a}}$ & $100.66^{\mathrm{a}}$ \\
\hline Grazing & 20 & $13.43^{b}$ & $9.76^{b}$ & $23.19^{b}$ & $85.12^{b}$ \\
\hline Tree lucerne & 10 & $16.10^{\mathrm{a}}$ & $4.66^{d}$ & $20.76^{b}$ & $76.18^{b}$ \\
\hline P-SW & & $* * *$ & $* * *$ & $* * *$ & $* * *$ \\
\hline P-LP & & ns & $* * *$ & * & $*$ \\
\hline P-LU & & * & $* * *$ & $* *$ & $* *$ \\
\hline
\end{tabular}

Means within columns under each topic followed by different letter(s) are significantly different from each other at $P \leq 0.05 ;{ }^{*}$ significant at $P \leq 0.05$; ** significant at $P \leq 0.01 ; * *$ significant at $P \leq 0.001 ; n s$ non-significant; equiv. equivalent 
Table 5 Effects of sub-watershed, landscape position, and land use on ecosystem carbon stocks

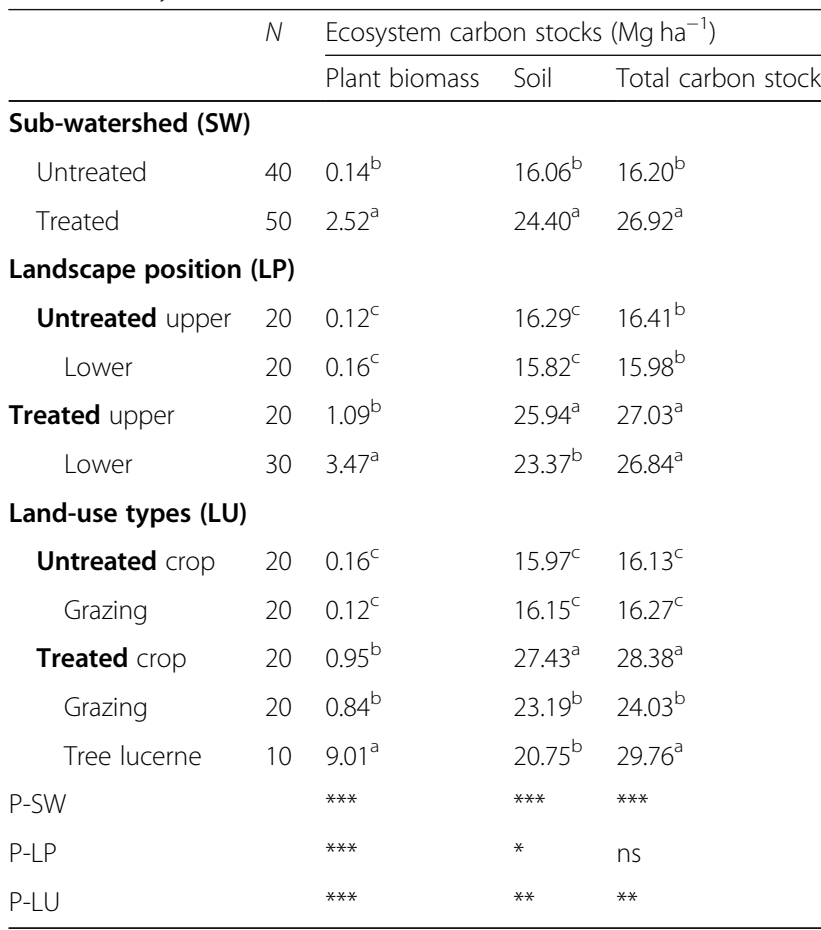

Means within columns under each topic followed by different letter(s) are significantly different from each other at $P \leq 0.05$; *significant at $P \leq 0.05$; **significant at $P \leq 0.01$;***significant at $P \leq 0.001$; ns non-significant

\section{Discussion}

Plant biomass production, biomass export, and carbon stock The higher plant biomass recorded in the treated subwatershed could be attributed by the introduced tree lucerne plants, increased biomass production due to the availability of soil moisture conserved by the structures

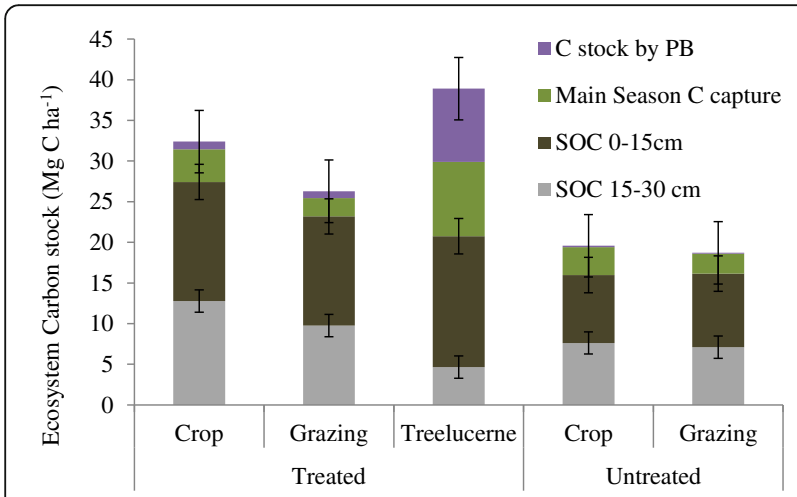

Fig. 5 Ecosystem carbon stock in Geda watershed: $\mathrm{C}=$ carbon, $\mathrm{PB}=$ plant biomass; SOC= soil organic carbon; $\mathrm{cm}$ : cent meters. $\mathrm{C}$ stock by $\mathrm{PB}$ is the sequestered carbon measured in the dry season; Main Season $C$ capture is calculated from the main season plant biomass production part of which later was exported from the treated subwatershed while almost all of which was exported from the untreated sub-watershed. Error bars represent standard errors of the mean

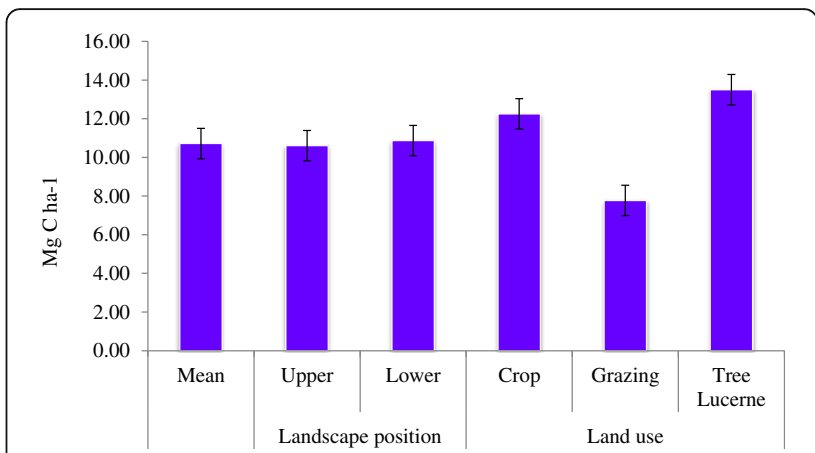

Fig. 6 SLM induced sequestered carbon by sub-watershed, landscape position and land use types calculated as a difference between carbon stock in the treated and untreated sub-watersheds. Carbon sequestration to tree lucerne was compared with the grazing land in the untreated sub-watershed. Error bars represent standard errors of the mean

and prohibition of free grazing. The multi-purpose plant, tree lucerne, is a good SLM element both for structural support and higher biomass production (Asmare and Gure 2019). Tree lucerne is a perennial plant that adapts well in a cool climate and sloped landscapes (vulnerable to soil erosion); it provides protein-rich fodder for livestock (Rajan et al. 2019), and it enhances soil fertility and livestock productivity (Mekonnen et al. 2017). In addition, availability of soil moisture is important to improve biodiversity and increase elasticity of plant growth, which further enhances the carbon sequestration capacity of plants (Nyssen et al. 2008; Wubet et al. 2013; Hishe et al. 2017).

Soil moisture protects plants from forced maturity and allows them to accumulate more biomass within the available resources and climatic conditions. We observed a strong positive correlation $(0.71$ and 0.69 at $20-\mathrm{cm}$ and $40-\mathrm{cm}$ soil depths, respectively) between plant biomass production and soil moisture in the study area (Table 2).

Prohibition of free grazing in the treated subwatershed could have contributed a lot to retain the sizable amount of plant biomass in the landscape, while nutrient export was comparatively higher in the untreated sub-watershed where free grazing is a common practice. This finding is in line with Girmay et al. (2008) who reported that uncontrolled free grazing destroys vegetation cover, reduces up to $23 \%$ topsoil carbon stock, and exposes the soil for erosion in Ethiopia. Furthermore, according to Tadesse and Penden (2002), grazing pressure decreases biomass production.

Other important explanations regarding higher plant biomass retained and enhanced soil organic carbon in the treated sub-watershed could be the problem of weed infestation. Weeds become more common on croplands in the treated sub-watershed. This discourages farmers 
to harvest the whole biomass of the plot at the soil surface; they rather harvest the crop selectively high above the soil surface, leaving behind the weeds and considerable amount of the crop straw at the bottom part. The overall effect is that more plant biomass is retained in the treated sub-watershed during the dry season. Following the higher level of biomass retention, there was also significantly higher carbon stock and sequestration in this landscape. Higher plant biomass production consequently captures more carbon dioxide from the atmosphere (Tesfay et al. 2019).

The finding in the current study agrees with the findings of Mekuria et al. (2011), Muluken et al. (2015), Ademe et al. (2017), and Asmare and Gure (2019). Ademe et al. (2017) found higher organic matter accumulation at the treated sub-watershed than the untreated one; Mekuria et al. (2011) reported an increase of 41 to $60 \%$ soil C stock and 83 to $87 \%$ above-ground C stock following the conversion of degraded grazing lands to exclosures. Further, they found a positive correlation between above-ground $\mathrm{C}$ stocks and moisture contents. Likewise, Muluken et al. (2015) and Asmare and Gure (2019) noted higher plant biomass from woody species in the exclosure than the adjacent open grazing areas.

Among the land-use types, tree lucerne provided higher plant biomass production and consequently higher carbon stocks in plant biomass. Thus, tree lucerne plantation at degraded landscapes in the study area might be an attractive component of the SLM option in the highland crop-livestock mixed farming system. Yet, the community in the study area seems not to support tree lucerne, they rather prefer eucalyptus. Currently, farmers are cutting tree lucerne from croplands and exposing the plant to free browsing and damage at grazing plots in the treated sub-watershed and promoting eucalyptus plantation instead. This could be due to the lower biomass production and lower timber production of tree lucerne compared to eucalyptus, the dominant plantation tree species in the area. In addition, its hindrance to the farm operation, especially during ploughing; low level of experience in the utilization of the foliage for livestock feed; and management of its shading effect on crops (personal communication with farmers) might be some of the reasons for low-level adoption of the tree lucerne in the study area.

Other deriving factors for expanding eucalyptus plantation in the treated sub-watershed than the untreated one might be low crop productivity of the treated subwatershed due to (a) space competition by the conservation structures (Adimassu et al. 2017; Dabi et al. 2017), (b) high weed infestation due to prohibited free grazing which could reduce weed seeds from subsequent germination, and (c) rodent infestation due to hiding structures.
Therefore, it is necessary to create strong awareness to the community regarding the management aspects of tree lucerne for its best performance and utilization (Mekonnen et al. 2017). Tree lucerne is a nitrogen-fixing plant that can be plated in combination with crops and grass in contrast to the highly dominant eucalyptus tree.

Nevertheless, substituting tree lucerne by eucalyptus plantation might bring even higher biomass production and consequently higher carbon sequestration. This practice would change the land use from crop production to plantation forestry which is in line with the land capability classification of these highly degraded landscapes. This could be an indirect positive influence of SLM interventions towards restoring degraded landscapes. Still, promoting eucalyptus plantation might also negatively affect fertile croplands; therefore, plot allocation for eucalyptus and tree lucerne should be carried out carefully in order to maximize the landscape productivity. Researchers and extension workers also need to consider farmers' preferences in selecting the type of tree they want to grow at degraded plots and help farmers identify proper niches for the plants as per the concept of land capability classification.

\section{Carbon stock in the soil}

The higher soil carbon stock in the treated subwatershed can be explained by the conservation structures through reduced soil erosion and increased plant inputs. The higher soil carbon stock in the cropland of the treated sub-watershed could also be due to the decomposition of higher plant inputs facilitated by tillage operations in this land-use type. Prohibition of free grazing could also contribute to the higher soil carbon stock in this landscape. According to Daniel (2015), plant biomass is the dominant source of soil carbon stock. The accumulated plant biomass in the study area could have been further decomposed and contributed to enrich the soil organic carbon as reported in the previous study (Terefe et al. 2020).

The lowest carbon stock observed in the sub-surface (15-30-cm depth) of the tree lucerne plot could be due to severe degradation of the plot before the intervention. Then, only the surface soil might have accumulated higher carbon stock in the given short period of conservation measures due to the rapid accumulation and decomposition of the tree lucerne litter as explained by Muluken et al. (2015).

\section{Ecosystem carbon stock}

This study illustrated that sustainable land management interventions increased ecosystem carbon stocks under all land uses when compared to the conventional practice (Fig. 6). Our finding agrees with the works of other scholars (e.g., Mekuria et al. 2011; Muluken et al. 2015; 
Manaye et al. 2019; Rajan et al. 2019). Mekuria et al. (2011) found higher carbon stock in the exclosure landscape that has better vegetation stock than the open grazing land, and soil carbon stock contributed the highest percentage (83-90\%) of ecosystem carbon stock compared with above-ground carbon stock in the exclosure. Manaye et al. (2019) also reported significantly higher soil organic carbon stocks in the exclosure associated with higher plant biomass and species diversity than in the adjacent open grazing land; further, they reported that the surface soil $(0-15-\mathrm{cm}$ depth) of the exclosure contributed about $57 \%$ of the total carbon stock compared to $55 \%$ in the open grazing land. In addition, Rajan et al. (2019) reported that tree lucerne sequestered $\mathrm{C}$ at the rate of about 6 tons of $\mathrm{CO}_{2}$ equivalent $\mathrm{ha}^{-1}$ year $^{-1}$ half which as soil organic carbon.

\section{Conclusion}

The sub-watershed treated with different SLM interventions showed improved plant biomass production, reduced plant biomass export from the landscape, enhanced carbon stock by plant biomass and the soil, and correspondingly captured significantly higher carbon dioxide equivalent compared to the untreated subwatershed. Land-use types differed significantly with higher ecosystem carbon stock observed in plots planted with tree lucerne and cropland compared to grazing land. Prohibition of free grazing was the key element of SLM interventions to reduce biomass export and increase carbon sequestration in the treated subwatershed. Tree lucerne is an $\mathrm{N}$-fixing plant that adds $\mathrm{N}$ into the soil, it is used for livestock feed, it controls erosion through stabilizing the physical structures, and also, it is a compatible plant with crop production. Furthermore, it is a fast-growing plant, adapts well in the highland ecology, and performs well in a highly degraded landscape. Thus, it is important to sustaining tree lucerne plants as a conservation measure in the study area. Yet, the acceptance of tree lucerne by the local community is abating and farmers want to replace it by the more profitable eucalyptus; thus, the effect of a eucalyptus tree on carbon sequestration should be of future interest.

\section{Supplementary information}

Supplementary information accompanies this paper at https://doi.org/10. 1186/s13717-020-00233-w.

\section{Additional file 1. Data.}

\section{Abbreviations}

ANOVA: Analysis of variance; Bd: Bulk stock; C: Carbon; EPA: United State Environmental Protection Agency; FAO: Food and Agriculture Organization of the United Nations; Fig.: Figure; GDP: Gross domestic product; IPCC: Intergovernmental Panel on Climate Change; masl: Meters above sea level; Mg: Million gram; OC: Organic carbon; SOC: Soil organic carbon; SLM: Sustainable land management

\section{Acknowledgements}

The authors highly appreciate the help of Dr. Abiyou Tilahun and Mr. Getahun Agumas in the course of this research work. We greatly acknowledge the reviewers of this manuscript.

\section{Authors' contributions}

All authors have contributed at different stages of this study. MA, LT, and KM involved in the design of the study, supervised the progress, and provided comments on the manuscript. HT designed the study, collected and analyzed the samples, and interpreted the data as well as wrote the draft manuscript. The authors read and approved the final manuscript.

\section{Authors' information}

Hailu Terefe is a lecturer and researcher at the Department of Plant Science, Debre Berhan University, Ethiopia. Hailu Terefe attended his BSc at the Department of Crop and Horticultural Science, Mekelle University, Ethiopia, and his MSc at the Department of Plant Science, Wageningen University and Research Center, The Netherlands. Currently, he is a PhD student at the Center for Environmental Science, Addis Ababa University, P.O. Box 1176, Addis Ababa, Ethiopia. Mekuria Argaw is an associate professor of Environmental Science at the Center for Environmental Science, Addis Ababa University, Ethiopia. Lulseged Tamane is a scientist in landscape ecology and resource management at the International Center for Tropical Agriculture. Kindu Mekonnen is a crop-livestock systems' scientist at ILRI, Addis Ababa, Ethiopia.

\section{Funding}

This research was done by the financial support from the post graduate offices of Addis Ababa University and Debre Berhan University, and Africa RISING, a program financed by the United States Agency for International Development (USAID) as part of the United States Government's Feed the Future Initiative. The content is solely the responsibility of the author/s and does not necessarily represent the official views of USAID or the U.S. Government or that of the Africa RISING program. Africa RISING is aligned with research programs of the CGIAR.

\section{Availability of data and materials}

The data set and materials used for this manuscript are available and can be shared whenever necessary. The data was generated by the author from the field sample collection, processing, and laboratory analysis (Additional file 1).

Ethics approval and consent to participate

Not applicable.

\section{Consent for publication}

Not applicable.

\section{Competing interests}

The authors declare that they have no competing interests.

\section{Author details}

${ }^{1}$ Center for Environmental Science, College of Natural Science, Addis Ababa University, P. O. Box 1176, Addis Ababa, Ethiopia. ${ }^{2}$ International Center for Tropical Agriculture (CIAT), P.O Box 5689, Addis Ababa, Ethiopia.

${ }^{3}$ International Livestock Research Institute (ILRI), P.O Box 5689, Addis Ababa, Ethiopia.

Received: 1 November 2019 Accepted: 8 May 2020 Published online: 23 June 2020

\section{References}

Ademe Y, Kebede T, Mullatu A, Shafi T (2017) Evaluation of the effectiveness of soil and water conservation practices on improving selected soil properties in Wonago district, southern Ethiopia. J Soil Sci Environ Manag 8:70-79

Adimassu Z, Simon L, Robyn J, Wolde M, Tilahun A (2017) Impacts of soil and water conservation practices on crop yield, run-off, soil loss and nutrient loss in Ethiopia: review and synthesis. Environ Manag 59:87-101 
Akudugu MA, Alhassan AR (2012) The climate change menace, food security, livelihoods and social safety in northern Ghana. Int J Sustain Dev World Policy 1:80-95

Amare T, Birru Y, Hans H (2013) Effects of "Guie" on soil organic carbon and other soil properties: a traditional soil fertility management practice in the central highlands of Ethiopia. J Agric Sci 5:237-244

Asante FA, Amuakwa-Mensah F (2015) Climate change and variability in Ghana: stocktaking. Climate 3:78-99

Ashagrie T (2009) Modeling rainfall, runoff and soil loss relationships in the northeastern highlands of Ethiopia, Andit tid watershed. MSc thesis. Presented to the Faculty of the Graduate School of Cornell University, 102 pp

Asmare MT, Gure A (2019) Potential of exclosure on aboveground biomass carbon stock and ecological fitness of woody species in Jabi Tehnane district, northwestern Ethiopia. Ecosyst Health Sustainabil 5:79-85

Birhanu A (2014) Environmental degradation and management in Ethiopian highlands: review of lessons learned. Intl J Environ Protect Policy 2:24-34

Conway D, Schipper ELF (2010) Adaptation to climate change in Africa. Challenges and opportunities identified from Ethiopia. Glob Environ Chang 21:227-237

Dabi N, Kalkidan F and Tewodros M (2017) Soil and water conservation practices on crop productivity and its economic implications in Ethiopia: a review. Asian J Agricult Res 11:128-36.

Daniel K (2015) Carbon sequestration potential on agricultural lands: a review of current science and available practices. National Sustainable Agriculture Coalition Breakthrough Strategies and Solutions, LLC, 36 pp

Deressa TT, Hassan RM, Ringler C (2011) Climate change and agriculture paper perception of and adaptation to climate change by farmers in the Nile basin of Ethiopia. J Agric Sci 149:23-31

Ebabu K, Tsunekawa A, Haregeweyn N, Adgo E, Tsegaye DM, Aklog D, Masunaga T, Tsubo M, Sultan D, Almaw AF, Yibeltal M (2019) Effects of land use and sustainable land management practices on runoff and soil loss in the upper Blue Nile basin, Ethiopia. Sci Total Environ 648:1462-1475

EPA (United State Environmental Protection Agency) (2002) Guidance on choosing a sampling design for environmental data collection. Office of environmental information. Washington, DC 20460. 178 pp.

FAO (Food and Agriculture Organization of the United Nations) (2012) Improving grazing land in Ethiopia. 4 pp.

FAO (Food and Agriculture Organization of the United Nations) (2014) Adapting to climate change through land and water management in Eastern Africa: results of pilot projects in Ethiopia, Kenya and Tanzania.178 pp.

Gashaw T (2015) Soil erosion in Ethiopia: extent, conservation efforts and issues of sustainability. Palgo J Agricult 2:38-48

Gebremedhin B, Pender J, Tesfay G (2001) Community resource management: the case of grazing lands in northern Ethiopia. International conference on African development archives. Paper 49.

Girmay G, Singh BR, Mitiku H, Borresen T, Lal AR (2008) Carbon stocks in Ethiopian soils in relation to land use and soil management. Land Degrad Dev 19:351-67.

Hishe S, Lyimo J, Bewket W (2017) Effects of soil and water conservation on vegetation cover: a remote sensing based study in the middle Suluh River basin, northern Ethiopia. Environ Syst Res 6:1-6

IPCC (2006) Guidelines for National Greenhouse Gas Inventories, Hayama, Japan: National Greenhouse Gas Inventories Program, Institute for Global Environmental Strategies Publishing. No. 4.

Issahaku ZA, Maharjan KL (2014) Crop substitution behavior among food crop farmers in Ghana: an efficient adaptation to climate change or costly stagnation in traditional agricultural production system? Agricult Food Econ 2:1-14

Keller M (2009) Climate risks and development projects: assessment report for a community-level project in Guduru. Oromiya, Ethiopia, 35 pp

Lewis F, McCosh J, Pringle C, Bredin I, Nxele Z (2011) Ecosystems, agriculture and livelihoods in the Lesotho highlands - likely futures and the implications of climate change. Lesotho climate change adaptation project Institute of Natural Resources NPC INR report: discussion document:165 pp

Liniger HP, MekdaschiStuder R, Hauert C, Gurtner M (2011) Sustainable land management in practice - guidelines and best practices for sub-Saharan Africa. TerrAfrica, world overview of conservation approaches and technologies (WOCAT) and food and agriculture Organization of the United Nations (FAO):246 pp

Manaye A, Negash M, Alebachew M (2019) Effect of degraded land rehabilitation on carbon stocks and biodiversity in semi-arid region of northern Ethiopia. For Sci Technol 15:70-79
Mekonnen K (2018) Africa Research in Sustainable Intensification for the Next Generation Ethiopian Highlands project; technical report, 01 April-30 September 2018. 37 pp.

Mekonnen K, Wellington J, Melkamu B, Annet M, Peter T (2017) Determinants of survival and growth of tree lucerne (Chamaecytisus palmensis) in the croplivestock farming systems of the Ethiopian highlands. Agrofor Syst 93:279293

Mekuria W, Veldkamp E, Corre MD, Haile M (2011) Restoration of ecosystem carbon stocks following exclosure establishment in communal grazing lands in Tigray, Ethiopia. Soil Sci Soc Am J 75:246-256

Muluken NB, Teshome S, Eyale B (2015) Above- and below-ground reserved carbon in Danaba community forest of Oromia region, Ethiopia: implications for $\mathrm{CO}_{2}$ emission balance. Am J Environ Protect 4:75-82

Nyssen J, Poesen J, Descheemaeker K, Haregeweyn N, Haile M, Moeyersons J, Frankl A, Govers G, Munro RN, Deckers J (2008) Effects of region-wide soil and water conservation in semi-arid areas: the case of northern Ethiopia. Z Geomorphol 52:291-315

Pearson T, Walker S, Brown S (2005) Source book for land-use, land-use change and forestry projects. Winrock international and the bio-carbon fund of the World Bank. Arlington, USA, $64 \mathrm{pp}$

Rajan K, Dinesh D, Rashmi I, Raja P, Ramesh M (2019) Prospective of tree lucerne in hilly areas for fodder, soil health and carbon sequestration: a review. Int J Forestry Horticulture 5:2454-87.

Tadesse G, Peden D (2002) Livestock grazing impact on vegetation, soil and hydrology in a tropical highland watershed. MoWR/EARO/IWMI/ILRI Workshop, Addis Ababa Ethiopia, pp 87-97

Tamene L (2017) Integrated watershed management interventions monitoring in Geda watershed in the Ethiopian highlands. Factsheet Geda. 2 pp.

Tamene L, Mekonnen K, Tesfaye Y (2015) Processes of managing collaborative model watersheds in Africa RISING sites: landscape/watershed visit organized for Africa RISING team members of the West Africa, southern and East Africa projects [PPT].

Terefe H, Argaw M, Tamene L, Mekonnen K, Recha J, Solomon D (2020) Effects of sustainable land management interventions on selected soil properties in Geda watershed, central highlands of Ethiopia. Ecol Process 9:14

Tesfaye MA, Bravo-Oviedo A, Bravo F, Pando V, de Aza CH (2019) Variation in carbon concentration and wood stock for five most commonly grown native tree species in central highlands of Ethiopia: the case of Chilimo dry Afromontane forest. J Sustain For 38:769-90.

Thomas R, Reed M, Clifton K et al (2018) A framework for scaling sustainable land management options. Land Degrad Dev 29:327.2-3284 .

Thornton PK, Herrero M (2015) Adapting to climate change in the mixed crop and livestock farming systems in sub-Saharan Africa. Nat Clim Chang 5:830836

Walkley A, Black IA (1934) An examination of the Degtjareff method for determining organic carbon in soils: effect of variations in digestion conditions and of inorganic soil constituents. Soil Sci 63:251-63.

Wilke BM (2005) Determination of physical and chemical soil properties. In: Margesin R and Schinner F (Eds) Manual of soil analysis: monitoring and assessing soil bioremediation. Soil Biology 5. Springer-Verlag, Berlin. pp 47-96

Wubet G, Alemu TA, Birru Y, Yihenew GS, Bettina W, Hans H (2013) Impacts of soil and water conservation on land suitability to crops: the case of Anjeni watershed, Northwest Ethiopia. J Agric Sci 5:95-109

Zerihun G, Gemedo D, James, GN, Tesfaye G (2011) Carbon stock assessment in different land uses for REDD+ in Ethiopia: practitioners field guide/manual. $28 \mathrm{pp}$

\section{Publisher's Note}

Springer Nature remains neutral with regard to jurisdictional claims in published maps and institutional affiliations. 